\title{
THE CONVERSATION IMPLICATURE IN PRESIDENT JOKO WIDODO RHETORICAL AND DIPLOMATIC SPEECH
}

\author{
Rangga Asmara and Widya Ratna Kusumaningrum \\ Universitas Tidar, Magelang, Indonesia \\ Jalan Kapten Suparman 39, Magelang, Indonesia \\ Corresponding Author: asmara@untidar.ac.id
}

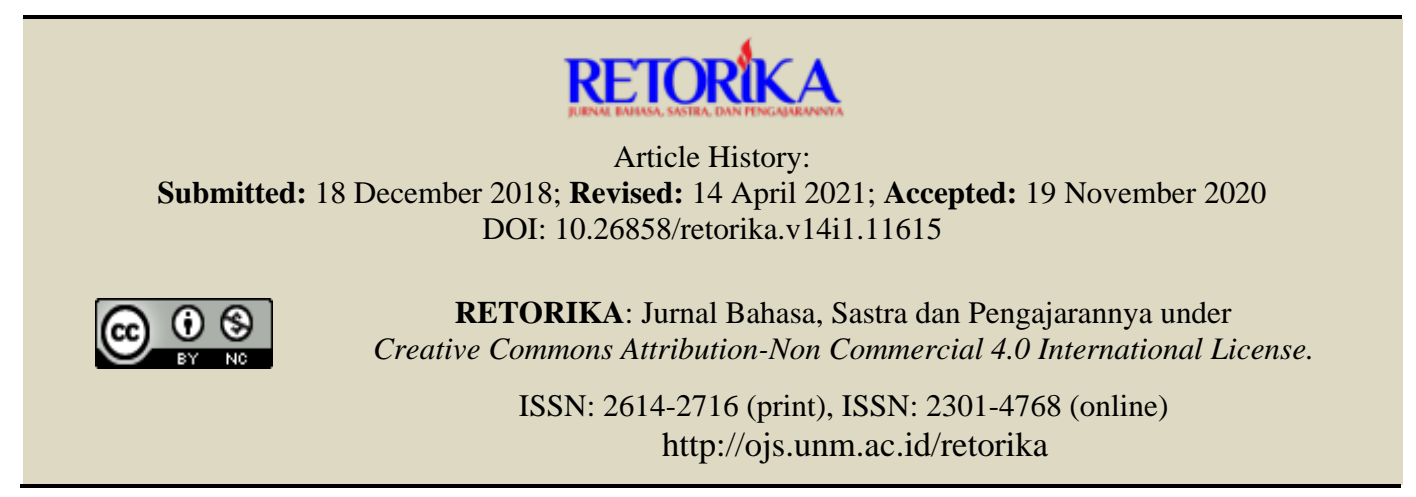

\begin{abstract}
The paper aims to describe the implicature used by President Joko Widodo in his speech on international forums. This study employs a pragmatic analysis approach to identify the implicative meanings of his speech. The data were the videos and texts of the transcription of President Joko Widodo's speech at the APEC CEO Summit Summit in Beijing on November 10, 2014 and the Asian-African Conference in Jakarta on April 22 2015. The data were analyzed by using note-taking techniques comprising two stages, (1) classifying linguistic data that contains implicatures and (2) interpreting the meaning behind the implicature used, based on the context of the situation and the background of the relevant discourse. Based on the results, President Joko Widodo's speech was dominated by several implicatures including influencing, insinuating, convincing, threatening, complaining, clarifying, and governing.
\end{abstract}

Keywords: critical discourse, implicature, Presidential speech, rethoricalc strategies

Barack Obama's success in winning the sympathy and voices of American was influenced by the strengths of his diplomatic and rhetoric speech. While in Indonesia, Sukarno was impressive for his communication and speech style. Being aware of its big effects, many political figures use speech as an effective media to convey ideas and thought and to control public perceptions (Asmara, 2016; Asror, 2015). Even, the speech functions to raise authority and power through its linguistic features aired on any media (Asror \& Sholehhudin, 2016; Sobur, 2006). Through speeches in the mass media, political figures try to win over people with their persuasion (Sulistyaningtyas, 2009). Speech as a form of persuasion discourse has the power to influence the target community so the speaker's intention can be understood, particularly a certain group ideology.

Van Dijk (1993) classified ideology in three dimensions of cognition, society, and discourse. Ideology is social awareness or fundamental beliefs that exist in the minds of all group members. The social dimension of an ideology explains the type of groups and relationships between groups or institutions that are involved 
on how development and reproduction of an ideology. The discourse dimension of an ideology explains (1) how ideology influences text and language, how we understand ideological discourse, and how discourse is involved as an effort to reproduce an ideology in society.

Speech as a text is an organized system of signalling that reflects certain attitudes, beliefs and values (Noermanzah et al., 2017; Sulityaningtyas et al., 2014). Each message in a speech has two elements of meaning, namely the surfacestructure meaning and deep-structure meaning (Asmara, 2016; Luhukay, 2007).

A presidential speech is a central source of information and the reflection of the proposed policies and agendas. As van Dijk (2006) highlighted that the presidential speech results a tension between the expectation and practices of political behaviour seen from its uttered language. Language plays it strategic role to build political images and reality.

President Joko Widodo's speech at international forums is interesting to be observed and in-depth studied from rhetoric and pragmatic perspectives due to President Joko Widodo's speech at these international forums has a strategic discourse. Broadly speaking, President Joko Wido-do's speech has rethoric and pragmatic implications as seen from (1) the role and position of actor, (2) and ideas which are delivered in the word choices, sentence-structure, and discourse to achieve particular goals (Nasiha \& Yunaldi, 2019; Sobur, 2006), while discourse is classified into three categories: (1) contents which are related to subjects that are said, (2) relation which is about the social relationship within particular discourse, and (3) position of a subject (Asror, 2015; Sobur, 2006). President Joko Widodo's speech implies a strategic discourse to build economic cooperation between two countries and to find Chinese investors.

As a form of rhetoric and pragmatic practices, President Joko Widodo's speech is not only perceived from linguistic perspective, but also as the ideology expression to form participants' opinions about his personal identity and Indonesian image in general. President Joko Widodo is considered as a non-talkative politician with his informal speaking style. His speech is dominated with spontaneity reflecting the personality of a person who grew from low-social class. Indeed, President Joko Widodo has a distinctive style of speech compared to the other former Indonesian presidents

President Joko Widodo's speech at international forums showed attractiveness complied with the influence attempts. This phenomenon is studied within the rhetorical studies. Rachmat generally defined rhetoric as the use of words or language to influence public thoughts, feelings, and behavior. For that reason, rhetoric cannot be detached from the use of languages, terms and symbols on certain topics and aspects. The use of some terms is ultimately able to direct the public thoughts and feelings to do the anticipated action.

The speech contents are packaged and developed with some implications that can lead listeners to make decisions and actions that are in line with government manisefto, nawacita. Wijana (1996) indicated that a speech may imply a proposition which is not the part of the uttered speech.

Brown \& Levinson (1987) described function of the implicature to explain the implicit intention of a speaker that is different with actual saying. In addition, the implicature puts its emphasis on a certain meaning that is different with the literal meaning. In this situation, implicature is not only approached with semantic theory but also with the speech theory.

Some studies offered fine-grained findings investigating the speech implicature from rhetoric perspective. Luhukay (2007) analyzed President Susilo Bambang Yudhoyono's (SBY) speech at the opening of the 2007 National Deliberation with the Aristotelian rhetorical approach and found that from the five Aristotelian's rethorical laws, the most dominant speech style was elucotio.

From the President SBY's speech text, the most important facet to influence audiences is ethos. Aristotle indicated that the ethos facet has three aspects, i.e., intelligence, character and goodwill. It can be inferred from the introduction of the President SBY's speech text and it builds President SBY credibility as the communicator (Luhukay, 2007). The main difference was Luhukay's study (2007) used the rhetorical analysis approach while this study used the pragmatic approarch with implicature analysis.

Research on President Joko Widodo's implicature was comprehensively discussed by Syaifudin (2017). This study describes the implicature of President Joko Widodo's speech in the Mata Najwa talkshow. Syaifudin (2017) used 
the observation as the technique of data collection and found that President Joko Widodo's speech on the Mata Najwa talkshow implied implicatures and particular meanings such as influencing, rejecting, convincing, satirizing, commanding, prohibiting, threatening, clarifying, and complaining. While Syaifuddin's study (2007) employed a dialogue text, this study proposed to analyse the monologue (speech).

Another study on the spoken implicature has been done by Astuti (2017) with the purpose was to describe implicature functions on the "Sentilan Sentilun" talk show on Metro TV with episode title "Siapa Ikut Gerobak?". This study used note-taking technique to document the utterances of the main characters and guests on the show. The results showed that (1) the implicature functions denoted the expressive implicature to criticize, express anger, insult, satirize, accuse, (2) the conversational implicature were resulted from violating maxims of manner and relation/relevance. While Astuti's study (2017) employed a dialogue text, this study proposed to analyse the monologue (speech).

Seen from discourse analysis, the proposed research question is investigating the implicature forms and meanings in President Joko Widodo rhetorical and diplomatic speech. It aims to examine the particular implicature form and meanings as a form of President Joko Widodo's indirect speech act within rhetorical and diplomatic discourse. This study offers a new horizon and paradigm of the President Joko Widodo's diplomatic and persuasive speech model.

\section{METHOD}

This study employed qualitative research design with pragmatic analysis on language functions. Pragmatic analysis is defined as a language analysis with a focus on pragmatic point of view (Asmara, 2015). This pragmatic analysis attempted to find the direct and implied meanings in the President Joko Widodo's speech. The implicative meaning on President Joko Widodo's speech could be only recognized through the use of concrete words by considering the speech situation components. Thus, this pragmatic analysis focused on the goal-oriented conversation analysis which connects between the conversation principles, or between the conversation principles and their functions (Leech, 2016).

The analyzed data were the video and speech text of President Joko Widodo's speech at the Asia-Pacific Economic Cooperation (APEC) CEO Summit Forum in Beijing Tiongkok on November $10^{\text {th }}, 2014$ (duration: 13 minutes) and the Asian-African Conference Commemoration (AACC) in Jakarta on April 22, 2015 (duration: 11 minutes). In both speeches, President Joko Widodo not only gave speech but also had power point presentations. To get the data, this study used documentation by collecting the data and downloading videos and speech texts from the government youtube channel www.setkab.go.id and observation (Sudaryanto, 1993) by identifying the language use.

Based on the techniques of collecting data, some used instruments were (1) the researcher, (2) observation sheet, and interview sheet. Moleong (2019) mentions that one of the qualitative researches is the use of humans as research instruments. The involvement researcher as a human instrument functions to determine research focus, to select participants, to gather data, to assess the data quality, to analyze data, to interpret the data, and to make a comprehensive conclusion based on the research.

Before deciding the validity argument, the data were re-read, checked, and intensified. This study provided validity arguments for the research data by triangulating the data from wideranging sources, researcher's opinions, and expert validation. In this qualitative study, triangulation was used to ensure the validity.

The data analysis technique used in this study was an interactive analysis model with three sequential stages: data reduction, data presentation, and drawing conclusions. These stages were interacted each other in a cyclical and iterative process (Huberman \& Miles, 2012). The data reduction began with selecting sentences and discourses in the President Joko Widodo's speech which implied conversational implicature and classified into its types.

The data were then analyzed by the intralingual and pragmatic methods. The intralingual method is used to classify and identify linguistic data that expressed conversation implicature, while the pragmatic method is to interpret the implied meanings based on the relevant discourse situation and setting. 


\section{FINDINGS AND DISCUSSION}

\section{Findings}

In the discourse of President Joko Widodo's speech that contextualizes diplomacy and rethoric facets implies some implicatures, such as influencing, insinuating, convincing, threatening, complaining, clarifying, and governing.

\section{The Discourse of President Jokowi's Speech that Implies an Influencing Implicature}

The President Joko Widodo's speech contextualizes diplomacy and rhetoric facets posits some examples of implicature that may influence the audiences as seen from data (1) to data (4).

(1) And we plan to build our railway track, railway network. Now we have already in Java and we want to build in Sumatera island, in Kalimantan island, in Sulawesi island and also in Papua island. This is your opportunity. (APEC)

(2) In 5 years we want to build 24 seaports and deep seaports. As you know, we have 17,000 islands, so we need seaports and we need deep seaports. And this is your opportunity: 24 seaports and deep seaports. (APEC)

(3) Some subsidy we want to channel to the fishermen, to give them boat engines, to give them refrigerators. We want to increase the income of the fishermen. Some fuel subsidy we want to give to micro and small enterprises in the villages. We want to help them raise their working capital. And some subsidy we want to channel to the health program, the education program. And some subsidy we want to channel to infrastructure. (APEC)

(4) We and the world are still in debt to the people of Palestine. The world has helplessly witnessed the suffering of Palestine's people, who live in fear and injustice under a protracted occupation. We cannot turn away from the suffering of the people of Palestine. We must keep struggling alongside them. We must support the Palestinian declaration of independence. (AACC)

In data (1) to data (3), President Joko Widodo employed multiple modalities in his speech discourse. Modality is defined as a statement of a sentence that states the speaker's attitude toward the interlocutor's actions, circumstances, events, or attitudes. The speaker's attitude is embodied in the form of a statement, possibility, desire, or even permission.

In Indonesian studies, modality is commonly stated in the lexical form [1] with the type of modality used by President Joko Widodo was intentional modality. The intentional modality is defined as a modality which states inclination, expectation, invitation and request [2]. This is indicated by some lexical elements such as plan, want, opportunity, need, keep.

The intense use of intentional modality shown by rhetoric and pragmatic implicatures on President Jokowi's speech contends his willingness to convince his audience. This excessive intentional modality is indicated by the use of the "want" marker. The speech discourse was constructed by employing data on the needs and shortages of infrastructure in Indonesia. This information was explicitly asserted to the Chinese investors as a profitable business opportunity. President Joko Widodo deliberately repeated the clause we want, we need, and this is your opportunity several times to influence his audience to do what he has said.

Meanwhile in data (4), President Joko Widodo tries to inspire the leaders of participant countries of the Asian-African Conference to help Palestinian declaration of independence. The discourse of the uttered statement (data 4) is coherently connected with the initial goals of the group, i.e, to raise awareness among the Asian and African nations to get the right to live as an independent nation, reject injustice, and oppose all forms of imperialism. The word in debt in his statement is to develop empathy of these leaders. Semantically meaning, the word in debt expects the listeners to help to pay it while the word injustice commands them to help the Palestinian declaration of independence.

\section{The Discourse of President Jokowi's Speech that Implies Political Satire}

The President Joko Widodo's speech contextualizing diplomacy and rhetoric facets may imply political satire, as seen from data (5).

(5) When there is a group of rich countries who feel capable to change the world by using their power, then the global 
imbalance will be clearly apparent when the $\mathrm{UN}$ is powerless. (AACC)

In data (5), President Joko Widodo appears to challenge the capacity and credibility of the United Nations as an intergovernmental organization which aims to maintain international peace and security and to develop friendly relations among nations, and to respect the human rights. In another part of his speech, President Joko Widodo used the word of global to replace the word of United Nation as the representation of a worldwide organization among nations. For him, the UN seems to be silent and helpless while witnessing the suffer of the Palestinian who live in fear and injustice due to Israel's long occupation. In his points of view, the United States which is a permanent member of the UN Security Council is affiliated with Israel and it makes the UN remain silent.

\section{The Discourse of President Joko Widodo's Speech that Implies Convincing Implicature}

The President Joko Widodo's speech contextualizing diplomacy and rhetoric facets may indicate the convincing implicature, as seen from data (6) to data (8).

(6) The view on an issue that world economic problems could be solved only by the World Bank, IMF, and ADB is an old paradigm that needs to be revamped. (AACC)

(7) Today, the world needs a global collective leadership which needs to be carried out fairly and responsibly, for this reason, Indonesia emerges as a new economic power, as the most populous Muslim country, and as the third largest democracy country on earth, and is ready to play a global role for peace and prosperity. (AACC)

(8) Via this forum, Ineed to attest my point of view that the world future would emerge from equator countries, in our hands, the Asian-African nations on two continents. (AACC)

Data (6) provide information on how Joko Widodo encourages the leaders of the AAC member countries not to be too dependent on the World Bank, IMF, and ADB when they face economic problems.
He contends that the AAC countries should have the spirit of Bandung that has been proposed by the heirs: welfare, solidarity, internal and external stability, and respect for human rights. President Joko Widodo is very optimistic that by working together, the AAC member countries could contributes to make the Spirit of Bandung comes true. Furthermore, he describes his plans to establish the Spirit of Bandung and to play a global role for peace and prosperity. With regard to his statement, he tries to convince the auidience on the need of a global leader and Indonesia meets the requirements as shown in Data (7) since Indonesia emerges as a new economic power with the largest Muslim population and third largest democratic rank and is ready to play an international role. At the end of his speech, he tries to make a substantial remark (see Data 12) that the world future woule emerge from equator countries, which means that in order to achieve the Spirit of Bandung Indonesia and other AAC countries play a central role.

\section{The Discourse of President Joko Widodo's} Speech that Implies Threathening Implicature

The President Joko Widodo's speech contextualizing diplomacy and rhetoric facets may indicate the threathening implicature, as seen from data (9).

(9) Violent acts without a UN mandate have negatively affected the existence of this world organization. Therefore, we urge for UN reformation. (AACC)

In data (9), it appears that President Joko Widodo criticizes the existence of the United Nations on which it has tolerated the Israeli occupation in Palestine. He forces a new reform within the UN bodies since the UN has internal interests towards the superpower countries such as the United States of America and affects the UN's attitude in responding to any international peace and conflict tragedies. The use of personal pronoun "we" which refers any nations within AAC circle has shown reciprocal coercive intentions. In semantic paradigm, the meaning of his utterance is to enforce the UN to reform its internal bodies; however, it has a pragmatic implication which urges the leaders of he AAC member countries to take an action. 
The Discourse of President Joko Widodo's Speech that Implies Complaining Implicature

The President Joko Widodo's speech contextualizing diplomacy and rhetoric facets may indicate the complaining implicature, as seen from data (10) to data (11).

(10) Many investors, a lot of investors, when they come to me, most of them they always complain about land acquisition. I will push my ministers, my governors, my mayors, to help clear this problem. I have experience with land acquisition when I was a governor. We have a project, the Jakarta Outer Ring Road, started 15 years ago but was stopped 8 years ago, because we have a problem here: 1.5 kilometers unfinished because there are 143 families who do not accept with the compensation price. So last year I invite them. I go to them then I invite them to lunch and dinner. Four times. $\mathrm{Ah}$, this is me. I invite them and then we talk about the problem. Four times. Four times meeting. And the problem is cleared. (APEC)

(11) The world we inherit from our ancestors is laden with injustice, inequality, and violence; meanwhile, the shared visions about the birth of a new civilization, a new world order with justice, equality, and prosperity principles are lucid. The global injustice and inquality are facing us. (AACC)

In data (10), President Joko Widodo indicates to be complaining about the land acquisition procedure which is a classical problem of the road construction. He expressed his complaining implicature with the word 'always' in the sentence "they always complain about land acquisition.". The diction signifies that the problem is a paradigmatic problem. In his presentation, President Joko Widodo indicates the difficult process and his efforts to regulate the land use permit. The data also clearly depicts how President Jokowi is trying to build an image as a progressive leader who has visionary ideas in overcoming investment problems.

In data (11), President Joko Widodo expresses his complaints about injustice, inequality, and violence in Middle Eastern and African countries. He described how hundreds of people in the northern hemisphere are associated with a super rich lifestyle, while 1.2 billion people in the southern part are helpless and earn less than 2 dollars a day. The endless conflicts happen in the Middle East because the United Nations has failed to carry out its role.

\section{The Discourse of President Joko Widodo's Speech that Implies Governing Implicature}

The President Joko Widodo's speech contextualizing diplomacy and rhetoric facets may indicate the governing implicature, as seen in data (12) to data (15).

(12) We have a project, the Jakarta Outer Ring Road, started 15 years ago but was stopped 8 years ago, because we had a problem here: 1.5 kilometers unfinished because there were 143 families who did not accept with the compensation price. So last year I invited them. I went to them then I invited them to lunch and dinner. Four times. Ah, this is me. I invited them and then we talked about the problem. Four times. Four times meeting. And the problem was cleared. And now the toll road has been used (starting) 7 month ago. (APEC)

(13) Many investors, a lot of investors, when they come to me, most of them they always complain about land acquisition.

I will push my ministers, my governors, my mayors, to help clear this problem. I have experience with land acquisition when $I$ was a governor. (APEC)

(14) Finally, again on behalf of the Indonesian government and the people of Indonesia, I would like to thank you for your listening (to) my presentation. We are waiting for you to come to Indonesia. We are waiting for you to invest in Indonesia. (APEC)

(15) We demand that international conflicts should not be solved by the use of force. These tasks and challenges need to be discussed in this AACC meeting. (AACC)

In data (12), it appears that President Joko Widodo used his power to govern the presidential elements in government system. As a president who did not to come from an elite political or military background, President Joko Widodo did 
not explicitly use the clause "I command", meanwhile uttered the clause "I invited them to lunch and dinner. Four times" to reflect his characteristics as an entrepreneur. In this clause, it is clear how President Joko Widodo orders his interlocutors to come to the State Palace (Istana Negara). In this context, President Joko Widodo emphasizes a mediation process rather than a direct instruction.

In data (13), it seems that President Joko Widodo employed an epistemic modality as a means to order which functions as a mandatory process, as seen in the clause "I will push my ministers, my governors, my mayors, to help clear this problem". In this context, President Joko Widodo ordered his ministers, governors, mayors to support the economic growth and employment and to monitor the land use permit process. Here, President Joko Widodo explicitly does not use the military clause such as "I order" but a more informal clause reflecting his previous background as an entrepreneur.

In data (14), President Joko Widodo changed the mode from a command sentence to a more inviting pattern. As a closing statement, President Joko Widodo indirectly order the potential Chinese investors to come and invest in Indonesia with a straightforward speech discourse. The clause "We are waiting for you to come to Indonesia. We are waiting for you to invest in Indonesia." siginifies a soft order maker that needs to be followed by the listeners.

In data (15), President Joko Widodo prefers to use a demanding diction which pragmatically means an order. As a host country for AACC, President Joko Widodo knows exactly that his speech is able to direct a recommendation and an implication. The use of diction "demand" indirectly means to order the AACC countries to play a significant role in resolving international conflicts, particularly in the Middle East. The AACC countries may act as mediators to stop the international conflicts and wars.

\section{Discussion}

In understanding the meaning of President Joko Widodo's speech, the researcher interpreted and made a number of assumptions about the uttered implicature based on contexts (problems, speech partners, and the background of the speech partners). Reflecting on the research findings, the implicature in Joko Widodo's speech is a form of narrative strategy and it is related to language politeness (Asmara et al, 2020).

The implicature position in the study of speech acts tends to be parasitic which sometimes an excessive implicature may imply an intention to affect speech partners' reaction. Talking about the issue, the implicature meaning in President Joko Widodo's speech to attract Chinese investors to invest in Indonesia, is not something exaggerating. The intended meanings in these implicatures cause infinitive meanings which should be understood by the investors. Syaifudin (2017) attests that an implicature can play a double role in communicative acts. It is appropriate that the use of strategies in communicative acts can save the meanings of implicatures. In line with this, Cummings (2013) contends that implicature in a conversation could be driven by politeness. President Joko Widodo, with his Javanese cultural background, states that the intended desire or hope is more polite than the explicit utterance.

\section{More than just Speech}

An assumption that President Joko Widodo is not a well-spoken politician seems to be objected. Although it was written, the President Joko Widodo used a speech style or spoken lamguage in persuading either investors from China or the leaders of the AACC countries. It is clear that the President Joko Widodo's rhetoric style sounds different from previous presidents of Indonesia.

From a rhetoric point of view, the strength of the President Joko Widodo's speech is the duration which is relatively short. The speech of President Joko Widodo on the APEC CEO Summit in Beijing, China on November 10, 2014 was around 13 minutes, while on the AACC in Jakarta on 22 April 2015 was shorter with 11 minutes. In general, a short speech is better than a long speech since the long speech may make the listeners get bored and it may deviate from the original messages.

Rakhmat (2000) asserts that the audience attention span to maintain their concentration is around 20 minutes. Longer than that, the audience starts to think other things and their memories may not be strong enough to capture the meanings. Therefore, the shorter the speech, the more understandable the message would be. It 
seems that President Joko Widodo understood this principle and implemented in his speech. To date, a short speech is less impressive and it causes people to compose a long speech. It relies on the fact that subject who delivers the speech is willing to convey many things and they neglected to see it deom the listeners who get bored easily. In this context, President Joko Widodo is aware with such situation. Not to mention, President Joko Widodo is not a talk-active person but it does not like to talk much. In every opportunity to talk in public, the dictions he prefers are spontaneous, straightforward, and strong.

The difference between speech and implication can sometimes make it difficult for investors to understand. However, when speakers and speech partners have shared experiences and knowledge with each other, the conversation can run smoothly. From his speech, it is clear that President Joko Widodo is a good at topicalization with two introductory paragraphs as the punch line of his speech. These two first paragraphs function as a means of sharing speaker's background by sharing experiences and knowledge. Topicalization technique in oral and written rhetoric statement is important to build the audience enthusiasm since the beginning. In this context, President Joko Widodo wants to make apperception to the audience that he has the same background as an entrepreneur.

Within a public speaking context, President Joko Widodo does not only give a talk but also, he tries to communicate with the audience. He spoke in front of the potential Chinese investors as if he did a transposition and switched his role from being a head of state to being a businessman. It seems that President Joko Widodo was aware of three aspects of discourse that he had to build in order to get the attention of his listeners, such as (1) contents (what to say or do), (2) relations (social relations that meet the discourse contexts), (3) subject (one's position) (Asror, 2015; Sobur, 2006).

Based on the genre, the President Joko Widodo's speech is a persuasive discourse. A persuasive discourse is a means to influence speech partners to take action as expected by the speakers (Asmara, 2018). In this context, he builds his discourse inductively by presenting a number of data, facts, problems, opportunities, and needs for infrastructure development in Indonesia. Based on the data corpus of his speech, President Joko Widodo repeated the word 'opportunity' seven times. Lexically, the word "opportunity" has persuasive intention to support the integrity of the discourse he wants to build among Chinese businessmen and professionals.

The diction he chose shows the ideological side of President Joko Widodo, who has a background from a businessman. For him, Chinese businessmen and professionals need to be broadly opened with the possible opportunities that can be obtained by investing in Indonesia.

Peggy Noonan, a speechwriter for the legendary US President Ronald Reagan, once said: "there is no great speech without great policy." In this context, President Joko Widodo's speech has touched on the most fundamental aspect of a speech: great policy. The message he conveyed was clear and straightforward, i.e., the opportunity to invest in Indonesia. His diplomacy and rhetoric do not only stop on the level of policy, but also on the mentality as part of the mental revolution that he wanted to promote.

\section{Breaking Habits}

As seen from his habits, President Joko Widodo is not a person who is good at speaking coherently for academic and literature discourse. He tends to speak practically without involving any figurative sentences. However, due to the suggestions of the speech writer, President Joko Widodo tends to break his habits.

In rhetoric, the technique for developing such arguments is known as sensory imagery technique. The strength of this technique lies on the involvement of the listeners' imaginary that may trigger all five senses to work. It is like inviting the listeners to visualize Indonesia as not only an abstract concept but also as a concrete entity which can be detected by the five senses. It seems that President Joko Widodo is able to elaborate the abstract concept with the concrete objects. It proves that this method is an effective way to convey the message to the listeners well.

The visualization of "the distance from west to east Indonesia is like London to Istanbul, it is a very wide distance." In that paragraph, the aim of the talk is not to reflect a literal concept but rather to provide visualization and depictions for the listeners. Not to mention, the use of a phrase of "a fairly large number" is able to make the listeners involve the five senses to understand the message. 
The repetitions of "the sea, the water, the ocean" and "today and tomorrow" three times are known as anaphora. Anaphora may add the cohesiveness of the sentence. The repetition of the phrase three times represents a magical number 3 . The speechwriters are aware about the rule of three and repeats the phrase three times. Although they sometimes modify it into four or five times of word/phrase repetition. In speech writing, effectiveness does not always mean efficiency, but the use of anaphora requires a more consideration and attention, i.e., if it is too often, anaphora tends to be clichéd and unattractive, or in the other words, the magical power of anaphora will decrease. In this context, President Joko Widodo's speech has a tendency that the anaphoric statements have lost their magical power.

\section{CONCLUSION}

In order to to persuade and win sympathy, President Joko Widodo played public speaking strategies which pragmatically implied indirect speech acts and implicature. The implicature in President Joko Widodo's speech has a number of meanings such as influencing, insinuating,

\section{REFERENCES}

Asmara, R. (2015). Basa-Basi dalam Percakapan Kolokial Berbahasa Jawa sebagai Penanda Karakter Santun Berbahasa. Transformatika: Jurnal Bahasa, Sastra, dan Pengajarannya, 11 (2), 80-95. https://doi.org/10.31002/transfor matika.v11i2.215

Asmara, R. (2016). Strategi Kebahasaan Presiden Joko Widodo dalam Menanamkan Ideologi dan Manifesto Pemerintahan. Litera, 15 (2), 379388. https://doi.org/10.21831/ltr.v15i2.11836

Asmara, R. (2018). Struktur dan Fungsi Bahasa dalam Wacana Iklan Pasta Gigi Sensodyne. Pertemuan Ilmiah Bahasa dan Sastra Indonesia, 459, 459-470.

Asmara, R., Kusumaningrum, W. R., \& Fortinasari, Paulina Besty, H. (2020). How does a celebrity politician's diction attract public empathy for parliamentary election? A critical discourse analysis. International Conference on Language and Language Teaching, 1-6. https://doi. org/10.4108/eai.12-10-2019.2292195

Asror, A. G. (2015). Bahasa Pencitraan dalam Iklan Kampanye Pilkada Kabupaten Bojonegoro. convincing, threatening, complaining, clarifying, and governing. One of the important reasons that orators often exploit implicatures in his speeches, including President Joko Widodo, is that they can provide an explicit explanation of how and how to imply more of what is being said.

From the discourse framework, President Joko Widodo's speech is a persuasive discourse and in developing his discourse, President Joko Widodo seems to be good at using a number of rhetorical sentences such as topicalization, sensory imagery, and anaphora.

The general assumption that short speeches are less impressive did not apply to President Joko Widodo's speech style. From a pragmatic and rhetorical perspectives, it seems clear that President Joko Widodo was aware of the dichotomy of the subject (speaker/ speech delivery) and object (speech partner/ listener) perspective. For this reason, he tries to build discourse and communication styles that integrate some aspects such as contents, relations and subjects. The speech style that seems spontaneous in conveying ideas make a presidential speech look semiformal and casual. However, this communication speech style would lead to closeness with his listeners.

Magistra, XXVII (92), 24-34.

Asror, A. G., \& Sholehhudin, M. (2016). Analisis Bahasa Pencitraan Iklan Politik Pilkada Kabupaten Tuban Tahun 2015. PEDAGOGIA: Jurnal Pendidikan, 5 (2), 197. https://doi.org/ 10.21070/pedagogia.v5i2.251

Astuti, W. D. (2017). Implikatur Percakapan dalam Gelar Wicara "Sentilan Sentilun" di Metro Tv. Kandai, 13 (2), 311. https://doi.org/10.26499/ jk.v13i2.306

Brown, P., \& Levinson, S. (1987). Politeness: Some universals in language usage. In Cambridge University Press. https://doi.org/10.2307/3587 263

Cummings, L. (2013). Pragmatics: A multidisciplinary perspective. In Pragmatics: A Multidisciplinary Perspective. https://doi.org/10.4324/978 1315045580

Huberman, A., \& Miles, M. (2012). Understanding and validity in qualitative research. In The Qualitative Researcher's Companion (pp. 3664). https://doi.org/10.4135/9781412986274.n 2 
Leech, G. (2016). Principles of pragmatics. In Principles of Pragmatics. https://doi.org/10.43 24/9781315835976

Luhukay, M. S. (2007). Presiden SBY dan Politik Pencitraan: Analisis Teks Pidato Presiden SBY dengan Pendekatan Retorika Aristoteles. Scriptura, 1 (2). http://puslit2.petra.ac.id/ejour nal/index.php/iko/article/view/16683

Moleong, L. J. (2019). Metodologi Penelitian Kualitatif. Bandung: PT. Remaja Rosda Karya. https://doi.org/ 10.1016/j.carbpol.2013.02.055

Nasiha, N. F., \& Yunaldi, A. (2019). Representasi Kecantikan dalam Iklan Slimmewhite (Studi Wacana Sara Mills). Al-MUNZIR, 12(1), 165. https://doi.org/10.31332/am.v12i1.1326

Noermanzah, N., Emzir, E., \& Lustyantie, N. (2017). Variety of rhetorics in political speech president of the republic of Indonesia Susilo Bambang Yudhoyono and Joko Widodo in educational field. Humanus, 16(2), 221-238. https://doi.org/10.24036/humanus.v16i2.8103

Rakhmat, J. (2000). Retorika Modern: Pendekatan Praktis. Bandung: Penerbit PT Remaja Rosdakarya. https://books.google.co.id/books? id=MGJ9AQAACAAJ

Sobur, A. (2006). Analisis Teks Media: Suatu Pengantar untuk Analisis Wacana. In Analisis Semiotik dan Analisis Framing. https://doi.org /10. 1177/1524838007302594

Sudaryanto. (1993). Metode dan Aneka Teknik Analisis Bahasa: Pengantar Penelitian Waha- na Kebudayaan Secara Linguistis. Duta Wacana University Press. https://books.google. co.id/books?id=uy5iAAAAMAAJ

Sulistyaningtyas, T. (2009). Bahasa Indonesia dalam Wacana Propaganda Politik Kampanye Pemilu 2009 Suatu Kajian Sosiopragmatik. In Jurnal Sosioteknologi (Vol. 8, Issue 17).

Sulityaningtyas, T., Suganda, D., Sobarna, C., \& Wahya, W. (2014). Representation of legislative member candidates of partai Demokrat on their outdoor political advertising. International Journal of Linguistics, 6 (2), 286. https:// doi.org/10.5296/ijl.v6i2.5553

Syaifudin, Z. K. (2017). Implikatur dan Kesantunan Positif Tuturan Joko Widodo dalam Talkshow Mata Najwa dan Implementasinya sebagai Bahan Ajar Bahasa Indonesia di SMK. Jurnal Penelitian Humaniora, 14 (1), 55-70. https:// doi.org/DOI: https://doi.org/10.23917/humani ora.v14i1.886

van Dijk, T. A. (2006). Ideology and discourse analysis. Journal of Political Ideologies, 11 (2), 115-140. https://doi.org/10.1080/1356931060 0687908

van Dijk, T. A. (1993). Principles of critical discourse analysis. Discourse \& Society, 4(2), 249-283. https://doi.org/10.1177/095792659300400200 6

Wijana, I. D. P. (1996). Dasar-Dasar Pragmatik. Andi Offset. https://books.google.co.id/books?id=r MGgAACAAJ. 